\title{
The Indonesian Government's Approach on a Human Rights-Based to Control the Spread of Coronavirus Disease (Covid-19)
}

\author{
Kevin Tobing ${ }^{1}$, Ningrum Natasya Sirait ${ }^{2}$, Huala Adolf ${ }^{3}$ \\ ${ }^{1}$ Universitas Padjadjaran. Bandung, Indonesia \\ ${ }^{2}$ Universitas Sumatera Utara, Medan, Indonesia \\ ${ }^{3}$ Universitas Padjadjaran, Bandung, Indonesia \\ Email:kevinarga09@gmail.com, ningrum.sirait@gmail.com, huala.adolf@gmail.com
}

\begin{abstract}
The purport of this article is to examine the Government Regulation in Lieu of Law No. 1/2020 enacted by Indonesian Government to controlling the spread of COVID-19 was meant to protect people's life or economy. National Commission of Human Rights in Indonesia (KOMNAS HAM) publish its report on governance of controlling COVID-19 in Human Rights' perspective, proclaimed Government put excessive effort to stabilize the economy. Therefore, research on the policy enacted by Indonesian Government to controlling COVID-19's transmission presumed on Article 3 Universal Declaration of Human Rights as an indicatory parameter for verifying the human rights value is necessary. The goal in this paper is to attain the view that Human Rights and Economy, respectively and directly, have the same important role in handling COVID-19 and have to be worked in parallel. in the Government Regulation in Lieu of Law No. 1/2020.
\end{abstract}

Keywords: COVID-19, Duty, Human, Rights

\section{INTRODUCTION}

As we know that currently, in the COVID-19 pandemic situation, everyone's health is threatened. Threats to the health of each individual are indirectly related to Human Rights, in particular the right to life based on Article 3 UDHR. The Indonesian Government's roles are maintaining and protecting the lives of its citizens by enforcing COVID-19 prevention policies and to minimize the weight of COVID-19.

On October $1^{\text {st }}, 2020$, the National Commission of Human Rights in Indonesia (KOMNAS HAM) published its report related to the policies enacted by the Government to control the infection of COVID-19 [1], KOMNAS HAM assessed the policy issued by the President of Indonesia in dealing with COVID-19 i.e. Government Regulation in Lieu of Law (PERPPU No. 1/2020), now has become Legislation No. 2/2020, contains the handling of COVID-19 based on an economic approach. Meanwhile, the establishment of PERPPU No. 1/2020 because a fast response was needed in an emergency to protect the community from the murky of COVID-19 and produced many policies related to the safety of people's lives [2].
This article specifically discusses the suitability of policies and other regulations imposed by the Government during the 2020 COVID-19 handling period that originates from or is related to PERPPU No. $1 / 2020$ in dealing with COVID-19, related to human rights, peculiarly the right to a decent life.

\section{RESEARCH METHOD}

This paper is using normative legal research method. The method is commenced by inspecting and checking the suitability of human rights principle and value in the Government Regulation in Lieu of Law No. 1/2020. In doing so, this research method conducted by harnessing Article 3 Universal Declaration of Human Rights as an indicatory parameter for verifying the human rights value and principles. Afterwards, Article 3 UDHR is synchronized with Government Regulation in Lieu of Law No. $1 / 2020$ to gain respective views on human rights and economy. 


\section{THE SIGNIFICANT ROLE OF GOVERNMENT REGULATION IN LIEU OF LAW No. 1/202O}

The President of Indonesia has the authority to issuing the Government Regulations in Lieu of Law to replace laws in critical circumstances (Article 22 (1) the Constitution of the Republic of Indonesia 1945), therefore, the President of Indonesia stipulates PERPPU No. 1/2020 Concerning State Financial Policy and Financial System Stability for Handling the 2019 Coronavirus Disease (COVID-19) Pandemic, and/or in the context of Facing Threats that Endanger the National Economy and/or Financial System Stability [3]. This regulation contains economic policies that ease the community, namely, increasing the time to 6 months for heaviness of taxpayer during the COVID-19 pandemic, moratorium of payments on People's Business Credit (KUR) for 6 months, the authority of the Minister of Finance regarding exemption or relief from import duty on imported goods, and etc.

Article 1 (3) PERPPU No. 1/2020 generating Presidential Regulation No. 54/2O2O regarding Modification in Posture and Details of the State's Budget for Fiscal Year $2 \mathrm{O} 2 \mathrm{O}$ [4], that contains a budget for conducting the control of COVID-19. Furthermore, based on PERPPU No. 1/2020 and Presidential Regulation 54/2020 generated a Joint Ministerial Decree (the Minister of Home Affairs with the Minister of Finance) concerning the adjustment of regional revenue and expenditure budgets pertaining to conducting the control of COVID-19 [5]. Then Article 1 (3) and Article 2 (2) PERPPU No. 1/2020 generated the Minister of Finance Regulation No. 38/PMK.02/2020 on the Implementation of State Financial Policies for Handling the COVID-19 Pandemic and/or Facing Threats That Endanger the National Economy and/or Financial System Stability, whereas Article 26 (2) Regulation No. 38/PMK.02/2020, contains provisions for prioritizing budget allocations to accelerate COVID-19 handling activities focused on the health facet, National Economic Recovery, and Social Safety Net.

\subsection{Procurement of Health Equipment and Medicines}

The total of stimulating fund that Central Government provided was Rp.677.2 trillion [6], and Rp.87.55 trillion in total, of the fund is allocated for spending in the health facet by each Regional Government [7]. The Regional Government involved MSMEs in the sphere of procurement of health equipment and medicines to deter the spread of Covid19 [8]. These deeds have two fold purposes [9], first, to focus on reallocating the budget aimed to procure medical equipment and medicines needed by referral hospitals for Covid-19 patients. Second, the collaboration between the Regional Government and MSMEs in the sphere of health aimed to recover the pecuniary loss of MSMEs' capitals so they could survive in the COVID-19 pandemic.

\subsection{National Economic Recovery}

The National Economic Recovery Program (NER) has two objectives, first, to diminish the output of Covid-19 on the economy due to the decline in people's purchasing power, and second, to safeguard and ameliorate the economic power of business actors during the Covid-19 pandemic [10]. Based on 2020 census data from the Indonesia Central Statistics Agency (BPS), Indonesia's population was 270.20 million [11], this infers the main support for growth of Indonesia's economic is public's consumption [12].

\subsubsection{Social Safety Network}

This program is known as Social Protection, and it is the extension of the NER program. The Social Safety Net (SSN) Program was formed by the Government because of the Large-Scale Social Restrictions (PSBB), led the entrepreneurs or companies reduced employees due to declining of sales, lack of capitals, and delayed distribution, causing an augmentation in the poor and in unemployment [13]. Therefore, the Government established the SSN program so people who have lost their jobs are able to fulfill their daily basic needs. The Central Government provided Rp. 203.9 trillion in total, in order to undertake the SSN Program [12]. The forms of the SSN program were: First, the Family Hope Program $(\mathrm{PKH})$ is a program that providing social assistance to vulnerable communities with budget Rp. 37.4 trillion in total [12], given to 10 million Beneficiary Families from January, April, June, and October 2020 [14]. Second, the Basic Food Assistance Program with budget Rp. 43.6 trillion in total [12], the Logistics/Food/Groceries Assistance Program with budget Rp. 25 trillion in total [12]. The Social Assistance Program for people in Non-Jabodetabek's area with budget Rp.32.4 trillion in total [12], the Food Assistance Program for people in Jabodetabek's area with budget Rp. 6.8 trillion in total [12] is a supporting program of daily food in the form of rice and cash (BLT) for 20 million Beneficiary Families based on Integrated Social Welfare Data (DTKS) [15], from April to December [14]. The recipients of the Food Assistance Program are divided into 10 million Beneficiary Families who receive regular rice assistance and 10 million Beneficiary Families who do not receive rice, will receive cash worth Rp.500,000 [16]. Third, the PreEmployment Card Program with budget Rp. 20 trillion in total [12], is a program aimed to provide assist to workers/laborers who were terminated from company or informal industry, with a total of 5.6 million recipients, and had received every month for 4 months from April 2020 [9]. Fourth, the Reduction of Electricity's Tariff Program with budget Rp. 6.9 trillion in total [12]. The reduction of the basic electricity tariff for customers with $450 \mathrm{Va}$ power of 24 million customers is free from April-June 2020, then for customers who have 900Va 
power as many as 7 million customers are only charged half from April-June [17]. Fifth, the Village Fund Direct Cash Assistance (VFDCA) Program, based on the Minister of Finance Regulation No. 50/PMK.07/2020 concerning Village Fund Management. The budget for this program Rp.31.8 trillion in total [12]. VFDCA is a financial aid aimed at families belonging to the less fortunate in the village, who receive the impacts of the COVID-19 pandemic. The requirements for BLT Village Fund recipients are [19], not receiving PKH assistance or not having a Pre-Employment Card, losing their livelihood so that there is no reserve fund for the next three months, and having a chronically ill family member. Funds received by underprivileged families from the Village Fund BLT are IDR 2,700,000/month for six months.

\subsubsection{Cash for Work Program}

This Program was made by the government to maintain people's purchasing power and build infrastructure in 34 provinces, with budget Rp.10 trillion in total. This program was supervised by the Ministry of Public Works and Public Housing. The description of the Intensive Work program includes Program for the Acceleration of Enhancement of Water Irrigation (P3TGAI), Typical Maintenance of Roads and Bridges, Regional Socio-Economic Infrastructure Development (PISEW), Slum-Free City Planning (KOTAKU), Reduce, Reuse, Recycle Waste Management Sites, Provision of Drinking Water and Community-Based Sanitation (Pamsimas) and Community-Based Sanitation (Sanimas), New Construction and advancement of Self-Support House Quality (Peningkatan Kualitas Rumah Swadaya) [22].

The execution of the labor-intensive program was undertaken by complying with health protocols such as wearing masks, maintaining distance and being limited to the number of workers in one work location. The implementation of the program had absorbed 630,900 workers. In addition to employment by the Cash for Work Program, through the PEN program, the Central Government provides additional funds of Rp.162.47 billion for the purchase of MSME products used in the Cash for Work program [23].

\section{HUMAN RIGHTS' PROVISIONS PERTAINING TO THE RIGHT TO HEALTH}

UNCHR had done a study on the response of COVID-19 based on Human Rights on April 2020 [24], which serves as a guideline for the Government of each country in carrying out these responsibilities. First, Article 3 of the UDHR implicitly has a very close meaning to the right to health [24]. This means that the Government must provide everyone, without exception, access to health care such as testing, intensive care and as quickly as possible specifically for people are infected with COVID-19 or for people who are vulnerable to COVID-19, and access to vaccines for the community. In addition, the assignment of government to overcome COVID-19 is to trace every person who is infected with COVID-19 to stop the spread [25]. Second, freedom of movement (Article 13 (1) UDHR) and Freedom to manifest one's religion or beliefs in house of worship (Article 18 ICCPR) could be restricted by reason of emergency power which related to public health for the sake of mitigating the infection of COVID-19 [24]. Third, the Government implements policies, such as policy of food assistance and daily necessities, policy of financial assistance for business actors and policy of financial assistance for employees which prevent them for being displaced, to reduce the negative impact on the country caused by COVID-19 [24].

In addition, the United Nations also provided matters that must be considered by the Government of each country in enacting policies for handling COVID19 in ways such as first, paying attention and ensuring the use of available resources for the need for the availability of medical equipment and improving the quality and accessibility of health care. Second, ensure that the stimulus policies provided by the Government to reduce the impact of COVID-19 are given to people with low incomes. Third, ensure that social assistance policies and income security policies adequately address everyone who has lost their livelihood.

\section{SUITABILITY OF INDONESIAN'S POLICIES ON CONTROLLING COVID-19 WITH ARTICLE 3 UDHR}

Being a member of the United Nations, Indonesia has a commitment as stated in Article 55 Paragraph 2 the Charter of UN to guarantee the human rights in its territory [26]. The action taken by the Government of each country to guarantee human rights in situation of the COVID-19 pandemic is to maintain the health of everyone as stated in Article 3 of the UDHR related to the right to life [27]. Based on these two legal bases, the Government of Indonesia has the responsibility to protect the lives of residents in its territory so that they are protected from COVID-19 and its impacts.

The form of responsibility is formed and the enactment of PERPPU No. 1/2020 which resulted in various policies/programs such as the procurement of medical equipment, social protection programs, and labor-intensive programs, as described above. Then the policy from the Government of Indonesia to protect its citizens related to restrictions on outdoor activities was realized by imposing social restrictions in April 2020, as contained in Article 1 (11) Legislation No. 6 Year 2018 pertaining to Health Quarantine [28], by publishing and enacting Government Regulation no. 21/2O2O regarding Large-Scale Social Restrictions (PSBB) in the Context of Accelerating Handling (COVID-19) [29], to stop the spread of COVID-19. Restrictions on community activities regulated during the PSBB period include temporary holidays in the education and office 
sectors, restrictions on religious activities carried out in places of worship and restrictions on the use of public facilities and tourism [30]. Interim Days off in the education and office sectors aim to make adjustments to activities that are usually carried out face-to-face in the education and office sector so that they can be carried out online. The results of the reformulation of activities in these sectors are issued by the Minister of Education [31], the Minister of Manpower [32], and the Ministry of Empowerment of State Apparatus [33].

\section{CONCLUSION}

Policies imposed by the President of Indonesia namely PERPPU No. 1/20 20 not only contain an economic approach in dealing with COVID-19, but also has rules regarding the protection of public health in the form of procurement of medical equipment for COVID19 referral hospitals. Either human rights or economy has the same significant role in handling COVID-19. Human rights value is used to understand what people need is, whereas the economy is regarded as vessel to push further to realization and embodiment for people needs. Therefore, the high health facilities can be realized and can carry out adequate testing and treatment. Based on the broad scope of meaning of Article 3 UDHR, the policies implemented by the Government of Indonesia are in accordance with Human Rights.

\section{REFERENCES}

[1] Tata Kelola Penanggulangan COVID-19 Dalam Perspektif HAM, $1^{\text {st }}$ October 2020, hlm. 1-214. Available from https://www.komnasham.go.id/files/20201012tata-kelola-penanggulangan-covid-\$\$RNP.pdf

[2] Perppu No. 1 Tahun 20201 Apa dan Mengapa?. Available from https://setjen.kemenkeu.go.id/api/Medias/84fca64 f-d08a-421f-b449-376a0fce0cc8

[3] Peraturan Pemerintah Pengganti Undang-Undang Republik Indonesia Nomor 1 Tahun 2O2O Tentang Kebijakan Keuangan Negara Dan Stabilitas Sistem Keuangan Untuk Penanganan Pandemi Coronavirus Disease 2019 (COVID- 19) Dan/Atau Dalam Rangka Menghadapi Ancaman Yang Membahayakan Perekonomian Nasional Dan/Atau Stabilitas Sistem Keuangan. Available from : https://peraturan.bpk.go.id/Home/Details/135060/ perpu-no-1-tahun-2020

[4] Peraturan Presiden Nomor 54 Tahun 2020 tentang Perubahan Postur dan Rincian Anggaran Pendapatan dan Belanja Negara Tahun Anggaran 2020. Available from https://peraturan.bpk.go.id/Home/Details/135243/ perpres-no-54-tahun-2020

[5] Keputusan Bersama Menteri Dalam Negeri dan Menteri Keuangan No. 119/2813/SJ, No. 177/KMK.07/2020 tentang Percepatan Penyesuaian Anggaran Pendapatan dan Belanja Daerah Tahun
2020 Dalam Rangka Penanganan COVID-19 Serta Pengamanan Daya Beli Masyarakat dan Perekonomian Nasional. Available from : http://www.bpkp.go.id/public/upload/unit/kaltim/f iles/SKB\%20Kemenkeu\%20Kemendagri\%20Covid_K MK-177.KMK .07.2020(1).pdf

[6] Pemerintah Gelontorkan Rp677,2 Triliun untuk Penanganan COVID-19. Available from : https://www.kemenkeu.go.id/publikasi/berita/pem erintah-gelontorkan-rp677-2-triliun-untukpenanganan-covid-19/

[7] Peraturan Menteri Dalam Negeri Republik Indonesia No. 20 Tahun 2020 tentang Percepatan Penanganan COVID-19 Di Lingkungan Pemerintah Daerah. Available from

https://peraturan.bpk.go.id/Home/Details/141351/ permendagri-no-20-tahun-2020

[8] KEMENKOP UKM SIAPKAN 5 LANGKAH KEBIJAKAN ATASI MASALAH UMKM DI MASA PANDEMI. Available from : https://kemenkopukm.go.id/read/kemenkop-ukmsiapkan-5-langkah-kebijakan-atasi-masalah-umkmdi-masa-pandemi

[9] St. Elmiana Febri Syahputri, Eka Arista Widya, Najma Nabiela, Azriel Auqi Attarsyah, Laila M. Pimada, Perspektif Ekonomi: Stimulus Pandemi Covid-19 Dalam Undang-Undang Nomor 2 Tahun 2020, Journal of Economic, Management, Accounting and Technology (JEMATech) Vol. 4, No. 2, Agustus 2021, hlm. 138-148.

[10] Program Pemulihan Ekonomi Nasional. Available from

https://www.kemenkeu.go.id/media/15149/progra m-pemulihan-ekonomi-nasional.pdf

[11] Rilis Bersama Data Sensus Penduduk 2020 dan Data Administrasi Kependudukan 2020. Available from

https://pringsewukab.bps.go.id/news/2021/01/21 L22/rilis-bersama-data-sensus-penduduk-2020dan-data-administrasi-kependudukan-2020.html

[12] Program PEN (Pemulihan Ekonomi Nasional). Available from https://www.kemenkeu.go.id/media/15366/phot ostory pen demandside.pdf

[13] Rahmi Rosita, Pengaruh Pandemi COVID-19 Terhadap UMKM, Jurnal Lentera Bisnis DOI : 10.34127/jrlab.v9i2.380 Volume 9 No 2, November 2020, hlm.1-12.

[14] PKH dan Kartu Sembako Penuhi Kebutuhan Dasar Masyarakat Rentan Miskin Terdampak COVID19. Available from https://www.kemenkeu.go.id/publikasi/berita/pk h-dan-kartu-sembako-penuhi-kebutuhan-dasarmasyarakat-rentan-miskin-terdampak-covid-19/

[15] Data Terpadu Kesejahteraan Sosial. Available from : https://cekbansos.kemensos.go.id/

[16] Tahap 2 Penyaluran JPS, Pemerintah Tambahkan Program Bantuan Beras dan Bantuan Uang Tunai. Available 
https://www.kemenkopmk.go.id/index.php/tahap -2-penyaluran-jps-pemerintah-tambahkanprogram-bantuan-beras-dan-bantuan-uang-tunai

[17] Keringanan Tagihan Listrik Bagi Pelanggan Rumah Tangga 450 VA dan 900 VA. Available from : https://web.pln.co.id/media/siaranpers/2020/04/begini-cara-dapatkan-keringanantagihan-listrik-bagi-pelanggan-rumah-tangga-450va-dan-900-va-subsidi

[18] Peraturan Menteri Keuangan (PMK) Nomor 50/PMK.07/2020 tentang Perubahan Kedua atas 205/PMK.07/2019. Available from : http://www.djpk.kemenkeu.go.id/wpcontent/uploads/2020/05/PMK-Nomor-50-Tahun2020-2.pdf

[19] Panduan Pendataan Bantuan Langsung TunaiDana Desa (BLT-Dana Desa) Juni 2020. Available from

https://www.bappenas.go.id/files/3415/9549/415 8/Buku Saku Pendataan BLTDana Desa FINAL.pdf

[20] BESARAN BLT DANA DESA NAIK JADI RP2,7 JUTA PER KELUARGA. Available from : https://jdih.bpk.go.id/?p=58128

[21] Program Padat Karya. Available from : http://www.djpk.kemenkeu.go.id/?ufaq=apakahyang-dimaksud-dengan-skema-padat-karya-tunai$\underline{2}$

[22] Kementerian PUPR Mulai Program Padat Karya 2020 di 34 Provinsi Sebesar Rp 10 Triliun Untuk Dorong Daya Beli Masyarakat Saat Wabah COVID-19. Availabe from : https://pu.go.id/berita/kementerian-pupr-mulaiprogram-padat-karya-2020-di-34-provinsisebesar-rp-10-triliun-untuk-dorong-daya-belimasyarakat-saat-wabah-covid-19

[23] Dukung Pemulihan Ekonomi Nasional, Kementerian PUPR Alokasikan Anggaran Rp. 1.36 T Untuk Pembelian Produk Rakyat/UMKM. Available from : https://pu.go.id/berita/dukungpemulihan-ekonomi-nasional-kementerian-pupralokasikan-anggaran-rp-1-36-t-untuk-pembelianproduk-rakyat-umkm

[24] COVID-19 and Human Rights We are all in this together APRIL 2020. Available from : https://unsdg.un.org/resources/covid-19-andhuman-rights-we-are-all-together

[25] Chih-Cheng Lai, Muh-Yong Yen, Ping-Ing Lee, Po-Ren Hsueh, How to Keep COVID-19 at Bay: A Taiwanese Perspective, Journal of Epidemiology and Global Health Vol. 11(1); March (2021), Atlantis Press, hlm. 1-5.

[26] Article 55 dan Article 56 Charter of the United Nations 1945.

[27] Abraham Magendzo, The COVID-19 pandemic: a challenge and an opportunity for human rights educators, Volume 3, No 2 (2020), Human Rights
Education Review, DOI: http://doi.org/10.7577/hrer.3996. HIm. 69-82.

[28] Undang-undang Nomor 6 Tahun 2018 tentang Kekarantinaan Kesehatan. Available from : https://peraturan.bpk.go.id/Home/Details/90037/ uu-no-6-tahun-2018

[29] Peraturan Pemerintah Republik Indonesia Nomor 21 Tahun $2 \mathrm{O} 2 \mathrm{O}$ tentang Pembatasan Sosial Berskala Besar (PSBB) Dalam Rangka Percepatan Penangan (COVID-19). Available from : https://covid19.go.id/p/regulasi/pp-no-21-tahun2020-tentang-psbb-dalam-rangka-penanganancovid-19

[30] Surat Edaran Menteri Pariwisata dan Ekonomi Kreatif/Kepala Badan Pariwisata Dan Ekonomi Kreatif Republik Indonesia No. 2 Tahun 2020 tentang Tindak Lanjut Imbauan Pencegahan Penyebaran COVID-19. Available from : https://jdih.kemenparekraf.go.id/static/pdf/regul ation subject 15860952522 tahun 2020.pdf

[31] Surat Edaran Menteri Pendidikan dan Kebudayaan Republik Indonesia No. 4 Tahun 2020 tentang Pelaksanaan Kebijakan Pendidikan Dalam Masa Darurat Penyebaran COVID-19. Available from : https://www.kemdikbud.go.id/main/blog/2020/0 3/se-mendikbud-pelaksanaan-kebijakanpendidikan-dalam-masa-darurat-penyebarancovid19

[32] Surat Edaran Menteri Ketenagakerjaan Republik Indonesia No. M/2/HM.01/III/2020 Tahun 2020 tentang Panduan Tindak Lanjut Terkait Pencegahan Penyebaran COVID-19 Di Lingkungan Kementerian Ketenagakerjaan. Available from : https://jdih.kemnaker.go.id/

[33] Surat Edaran Kementerian Pendayagunaan Aparatur Negara Dan Reformasi Birokrasi Nomor 19 Tahun 2020 tentang Penyesuaian Sistem Kerja Aparatur Sipil Negara (ASN) tentang Penyesuaian Sistem Kerja Aparatur Sipil Negara Dalam Upaya Pencegahan Penyebaran COVID-19 Di Lingkungan Instansi Pemerintah. Available from : https://bkpsdm.palangkaraya.go.id/berita276/surat-edaran-kementrian-pendayagunaanaparatur-negara-dan-reformasi-birokrasi-nomor-19-tahun-2020-tentang-penyesuaian-sistem-kerjaaparatur-sipil-negara-dalam-upaya-pencegahanpenyebran-covid19-di-.htm

[34] Djalante, Riyanti and Nurhidayah, Laely and Lassa, Jonatan and Minh, Hoang Van and Mahendradhata, Yodi and Phuong, Nguyen Thi Ngoc and Trias, Angelo Paolo L and Miller, Michelle Ann and Djalante, Susanti and Sinapoy, Muhammad Sabaruddin, The ASEAN's Responses to COVID-19: A Policy Sciences Analysis (May 1, 2020). Available at SSRN: https://ssrn.com/abstract=3595012 or http://dx.doi.org/10.2139/ssrn.3595012

[35] Press Release on Coronavirus Disease 2019 (COVID-19) by the ASEAN Intergovernmental 
Commission on Human Rights (AICHR).

Available from : https://asean.org/press-release-

on-coronavirus-disease-2019-covid-19-by-theasean-intergovernmental-commission-on-humanrights-aichr-2/

[36] ASEAN Human Rights Declaration. Available from : https://asean.org/asean-human-rightsdeclaration/ 